\title{
English for Tourism and Hospitality Purposes (ETP)
}

\author{
Nahid Zahedpisheh ${ }^{1}$, Zulqarnain B Abu bakar ${ }^{1} \&$ Narges Saffari ${ }^{1}$ \\ ${ }^{1}$ Department of Management and Social Science, Language and Communication Unit, University Technology \\ Petronas, Perak, Malaysia \\ Correspondence: Nahid Zahedpiaheh, Department of Management and Social Science, Language and \\ Communication Unit, University Technology Petronas, Perak, Malaysia. Tel: 60-174-472-793. E-mail: \\ nahid.zahedpisheh@gmail.com
}

\author{
Received: May 31, 2016 Accepted: August 3, 2017 Online Published: August 8, 2017 \\ doi: 10.5539/elt.v10n9p86 URL: http://doi.org/10.5539/elt.v10n9p86
}

\begin{abstract}
The quick development of the tourism and hospitality industry can straightly influence the English language which is the most widely used and spoken language in international tourism in the twenty-first century. English for tourism has a major role in the delivery of quality service. Employees who work in the tourism and hospitality industry are entirely and highly aware of its importance and they need to have a good command of English in their workplace. English for tourism and hospitality has been categorized under English for the specific purpose (ESP). It is an important and dynamic area of specialization within the field of English language teaching and learning. The necessity of teaching English for professional purposes and specifically in the area of tourism is irrefutable. Language proficiency is very important and essential in all professional fields specifically in the tourism and hospitality industry due to its specific nature and concepts. Thus, it is required that the educators understand the practical applications of this approach. This paper aims to provide an overview of the purpose of teaching ESP (English for Specific Purposes) and ETP (English for Tourism Purposes) to the learners and users. In addition, characteristic features of ESP and ETP concerning course development, curriculum planning, learning style, material development, English efficiency, types of activities and evaluation are outlined. Determining the ESP concepts and elements provides specific English instruction that could help the learners be well-prepared for meeting their workplace requirements.
\end{abstract}

Keywords: ESP, ETP, tourism, English language, features

\section{Introduction}

Most of the time we hear the terms like English for civil engineering, English for computing, English for music, English for medicine, English for business and so forth. English for tourism and hospitality is used for international tourism and service industry which is considered under the category of English for specific purposes and its practical application needs to be understood (Cravotta, 1990). English has been dominated in many different fields such as education, business, technology, media, research, tourism, and medicine. According to Tsao and $\mathrm{Xu}$ (2008), there is a fast rise and demand for English for specific purposes to achieve people with instrumental purposes. English for specific purposes is recommended to the learners who are required to meet the essential, specific and precise needs to respond to the considerable demands in vocational or academic situations in English (Chang, 2009; Tsao, 2011). Hutchinson and Waters (1987) agree that one approach to the language teaching is ESP. They believe that all decisions as to the different methods and content are constructed based on the learners' intention and purpose for learning. According to Strevens (1988), ESP is designed and aimed to see the definite needs of the learners.

Simion (2012) states that, with the development of business management and communication technologies in the recent years, some changes have been made in the field of English language teaching. One of these changes is that the attention of course designers from teaching English for academic purposes has been altered and improved to teaching English for more specific purposes (ESP). In fact, differences between the ESP learners and ELT learners is that ESP learners are the ones who are nearly aware and familiar with English, however, they are still required to learn the language to perform particular job-related functions and to be able to communicate a set of professional skills (Lorenzo, 2005). According to Hutchinson and Waters (1987), three important reasons for the emergence of ESP are the new focus on its learners, request, and demand in the new world, and revolution in the field of linguistics. ESP features and characteristics were defined by Dudley-Evans (1998). The 
first characteristic explains that the particular need of the learners is identified through the ESP. The second characteristic is that ESP utilizes the specific activities of the discipline and principal methodology. Finally, the last characteristic states that ESP concentrates on the appropriate language learning for the skills of study, genre, lexis, grammar, and discourse.

English for specific purposes is a term that refers to teaching or studying English for a particular career (like law and medicine) or for business in general (International Teacher Training Organization, 2005). Robinson (1989) believes that ESP is considered as a type of English Language Teaching, ELT and it is a kind of goal-oriented language learnin. In goal-oriented language learning the learners are required to obtain a definite purpose in the learning process. In fact, ESP is considered as a main subject or topic that can promulgate competence into the hospitality and tourism preparation and training programs (Hsu, 2011). To make it clear, in the language learning process, English is not considered as the main purpose; it is only seen as a vehicle for its acquirement. According to Robinson, Pauline C., ed. Hywel Coleman (1989), students learn and study English because they are required to perform and complete a task in English not because of their interest in the English language. This edict of English language has to help them to attain a good and satisfactory level in their individual and professional subject studies.

There are numerous of sub-divisions under the umbrella term of ESP. For example (EBP) which is called English for Business Purposes, (EAP) which is employed for English for Academic Purposes, English for Occupational Purposes (EOP), and English for Medical Purposes (EMP), and many others with new ones being added yearly to the list. In fact, EOP which is known as English for Occupational Purposes is more general and common in comparison with ESP. Simion (2012) states that, all of the main and fundamental English skills such as reading, writing, listening and speaking in EOP are exactly the same as ESP. In other words, its concentration is not in the particular profession disciplines; however, it is basically based on general skills that are essential for the learners to be prepared for their future workforce.

According to Dudley-Evans and St. John (1998), "the teaching process of any kind of language for occupational purposes (EOP) need to be considered as a starting point and the analysis of the four traditional skills within an appropriate context, that being, as far as possible, the conditions given in the workplace".

Hortas (2008) believes that EOP programs are needed to more focus on developing communicative competence in a specific field, such as aviation, business, or tourism. Accordingly, the command of ESP and EOP must be such that the learners can reach a satisfactory level in their specialist subject matters and career.

Prof. Huang (2008) constructed a complete and comprehensive model for the English for Specific Purposes curriculum which is applicable for hospitality and tourism English.

Table 1. Model for tourism and hospitality English curriculum

\section{Dimension of the tourism and hospitality curriculum}

1. English for Food and Beverage Services

2. English for Air Flight Services

3. English for Hotel Services

4. English for Tour Managers and Guides

English curriculum design for hospitality by Huang Chao-shain (2008).

Regarding the English proficiency to fulfil job responsibilities in the tourism sector, all the activities that guests and hosts experience may involve interactive communication, and tourism employees are required to follow and use specific professional conversations, language, vocabularies and speech matter when serving guests (Blue \& Harun, 2003).

\section{Review of the Litrature}

Much attention has been given to teaching English for tourism due to using English as a lingua franca in international tourism and travel contexts. Some studies on tourism and hospitality English have dealt with subjects such as checking out the effectiveness of courses and interventions in developing and expanding tourism students' language competence (Akyel \&Yalcin, 1991; Fuentes, 2004; Haggag, 2008; Lo \& Sheu, 2008; Luka, 2009; Watts \& Trim, 1999; Zayed, 2009). Moreover, there are some other studies investigating the language 
needs of students and employees (Afzali \& Fakharzadeh, 2009; Choi, 2010, Al-Khatib, 2005; Martin \& Davies, 2006; Stapa, 2005; Tipmontree, 2007). Brunton (2009) and Laborda (2005) in their studies have addressed the evaluation of language materials and course books from the perspectives of trainees, employees, and students. Laborda $(2003,2009)$ investigated the incorporation of computer-based activities in English courses for tourism students. Other issues investigated by the similar studies included teachers' perception on oral communication activities help developing tourism students' oral English (Jing, 2010). Diaz and Scholfield (2010) did a research on the relationship of general English high-frequency words and the most frequent tourism English vocabulary with the tourism students' reading comprehension of texts in their English courses.

In the field of English for tourism and hospitality, many of the studies are focusing on the strategies, appropriateness of in structural materials and adequacy. Comparison between the communicative needs of tourism employees and personnel of the banks were done by Al-Khatib (2007) to shed some lights on the attitudes towards the lack, needs and wants. In his study, he also investigated the participants' realization toward English to know what they need more to be included or what they considered less important to be excluded. In his study, he observed that in applying and evaluating staff English proficiency the type of work has a significant role. Travel agency staff believed that the most common reasons for communicating were writing and sending email and faxes, making on-line ticketing, browsing the internet, making online hotel booking and offering destination guides. Moreover, in this study, the most important skill for tourism employees was writing and travel agency employees used English more than banking staff at their workplace. Thus, developing and instructing an ETP course is an important issue that has to take into account. The reason is that using professional strategies and sufficient language learning is required in the tourism field.

In fact, people who are required to use English at work for tourism and hospitality purposes need to improve their communicative abilities, language fluency, and accuracy. These people in international tourism and service industry have the opportunity to apply and utilize the target language in their activities and routine work. Cravotta (1990) states that mastering English for Tourism Purposes (ETP) p provides people with the required linguistic tools to work in the different chosen professions.

\section{English for Tourism Purposes (ETP)}

According to Leslie \& Russell (2006), being skillful in foreign language skills is necessary for people working in the tourism and hospitality sector. The reason is that it is the means for having communication with foreign tourists and understanding cultural differences. In fact, for those who are seeking employment in the tourism, hospitality and service industry, it is essential to stay highly motivated in order to be accurately fluent in a high level of professional service language. In fact, they are required to become proficient in English for Tourism Purposes (Cravotta, 1990). Moreover, Cho (2005) believes that English for tourism is viewed as an area of business English and incorporate business English and English for academic purposes by bridging workplace communication and classroom use. This can help to increase the job opportunities in the international industry.

English for tourism is known as one of the attractive subjects since many of the people will be a tourist at least once in their lifetime. Moreover, learning English for tourism purposes is crucial for those who are working in guest-host relation section such as hotels, travel agencies, restaurants, information centres and tourist attractions. In industrial sectors, English has recently become a core subject, and hospitality training programs help the employees achieve English proficiency to fulfil the job responsibilities (Hsu, 2010; Chen, Chiu, \& Lin, 2011; Kuppan, 2008).

According to Buhler (1990), English for tourism is comparable to other languages and can be examined by principal properties such as functions, structures, and tenses. In fact, English for tourism is a structured language and follows definite grammar rules. Dann (2001) states that the vocabulary used in the English for tourism is special and conveys messages through a conventional system of symbols and codes. For instance, the language used for checking into a hotel, giving information about hotel facilities, meal times, giving directions, requesting and giving tourist information, and other communicative activities that can take place in any hospitality setting.

Strutt (2003) in his introduction, describes his textbook (English for International Tourism) as needing no specialized knowledge 'it is not technical or over-specialized in nature.' In fact, ESP textbooks are significantly similar to any general English textbook. For instance, grammar in these books is used as a means of structure. However, all the examples are used within the tourism, medicine, or business context make a distinction from a usual ELT textbook (Brieger \& Sweeney, 1994).

In fact, English for Tourism Purpose (ETP) is important for its learners since it helps be equipped with the specific domains of language skills and knowledge. Consequently, learning the specific skills in English helps apply them properly and appropriately in the specific professions, workplace, and discipline. Because of this, a 
particular language need of the specified context has a critical role as a requirement to apply a successful language (Shieh, 2012).

\section{Characteristics and features of ESP and ETP courses}

\subsection{Curriculum Designing}

According to Edwards (2000), when we design a curriculum for ESP courses in the field of ETP (English for Tourism Purposes) learning tasks and activities should have a high surrender value, it means that "learners could be able to use what they have learned to perform their jobs more effectively" (p. 292). Gardner and Walqui (2000) believe that designing a course based on this belief can enhance the learners' inherent motivation which can aid and support their learning process. McCarten (2007, p. 26) states:

'Making vocabulary personal helps to make it more memorable.'

According to Hutchinson and Waters (1987), all the decisions regarding ESP courses are supposed to be based on the learners' rationale for learning. Johns and Evans (2001) claim that when we apply a curriculum design or syllabus "the students" target English situations have identifiable elements (p. 117). Therefore, the process of curriculum design can proceed once the elements have been recognized. Unfortunately, these days many of the ESP courses are surrendered without a target situation analysis being carried out. Several factors have been considered and measured in teaching ETP by the educators in designing curriculum, individual courses, and classroom materials which can assist the learners to increase their motivation very rapidly and improve their language skills. Nunan, (1987) states that educators engaged and responsible in using English for tourism purpose (ETP) as a theoretical framework have numerous roles and duties. Nunan (1987) tried to make several observations about educators who design and develop curriculum and noticed that improving the curriculum needs skill, time, and major support. The abilities required for successful communication in occupation settings, content language acquisition versus general English acquisition and those important issues in ESP curriculum design. In addition, the acquisition of English for tourism purposes (ETP) has to consider these main factors within an international context (Nunan, 1987).

\subsection{Organizing Course}

One of the important steps to achieve a satisfying goal is organizing the ESP course. There are many factors that play a crucial role in organizing the ESP course. Without them, the learning process would not lead to effectiveness. In ESP, the term specific refers to a specific purpose for which English is learned and teachers are required to be familiar with. The teachers have to be able to find a good response to what Hutchinson and Waters (1992) describe as language description. In fact, there are some questions that emerge from the language description, e.g. "What do the students need to learn?" "What topic areas are needed to be covered?" "What aspects of language will be required and how will they be described?" (Hutchinson \& Waters, 1992). Finding the right answers to all of these questions will result in setting exact aims and objectives of the course. In fact, syllabus analyses designs regarding what the course is going to be about, objectives of the course and setting goals are unavoidable.

Moreover, the way of the learning process is another feature of organizing a course. According to Hutchinson and Waters (1992), the theory of learning prepares the theoretical basis for the methodology. It will help to figure out how the people learn. In fact, the strategies of learning are different parallels with learners' level, age and the reason for the study. The way a group of beginners acquires language varies from the advanced, or the adult learners expect a different attitude from the children.

Teachers are required to specify which aspects of ESP learning will be focused on to meet the learners' expectations and needs successfully. Hutchinson and Waters (1992) state another aspect affecting the ESP course. It relates to the discussion of the questions of 'why', 'who', 'when' and 'where' allied with the nature of learning situation and a particular target. They define them as needs analysis (p. 22). To establish and organize the ESP course effectively and consequently, achieving a satisfactory goal and having respect for all these factors is obvious.

\subsection{Learning Style}

Learning styles for the tourism, travel, and hospitality are different from other English programs. (Barron \& Arcodia, 2002; Dale \& McCarthy, 2006). According to Cassidy (2004), a learning style integrates people's affective, cognitive, and psychological traits. Conner (2007) believes that learning styles are mainly related to processes, learners' perception, organization, and present information developed during the past decades. In 1987, Neil Fleming developed VARK, and its seminal publication appeared in 1992. Fleming showed that people have preferred sensory routes for learning based on learner type. He classified them as the four learning styles of the 
VARK model (Visual/seeing, Aural/listening, Read/Write, Kinesthetic/experiencing). Moreover, Honey and Mumford (1995) investigated four major learning styles in which learners have a preferred learning style that determines how they enjoy learning the theorist, pragmatist, activist, and reflector.

Studies have indicated that learners are more attracted to practical activities rather than theory and reflection. As a result, educators are required to instruct and educate the learners through different teaching styles to increase their learning preference in certain programs (Barron \& Arcodia, 2002; Lashley, 1999; Lashley \& Barron, 2006; Dale \& McCarthy, 2006).

\subsection{Selecting Material}

Good ESP materials should assist the teachers in organizing the course or what is more it can function as an introduction to the new learning techniques. It will support teachers and learners in the process of teaching and learning. To make it clear, choosing ESP materials determines the running of the course and underlines content of the lesson. Furthermore, materials are also a kind of teacher reflection. They can truly mirror what you feel and suppose about the learning process (Hutchinson \& Waters, 1992). In fact, good materials are expected to be based on activities and various interesting texts providing a wide range of skills. Teachers are required to specify which aspects of ESP learning should be focused on. However, one piece of material can serve for expanding more than one skill, e.g. vocabulary, reading, writing, speaking, etc. "Teaching materials are tools that can be figuratively cut up into component pieces and then rearranged to suit the needs, abilities, and interests of the students in the course"'(Graves, 1999, p. 27).

Hutchinson and Waters (1992) state that it is the teachers' responsibility to be aware of the fact whether the selected materials are suitable not only for a specific discipline and answers are given course goals but also for learners and teachers themselves. Materials have to function as a link between already learned, existing knowledge and new information. Consequently, selecting a proper and appropriate material regarding the main criteria is a crucial part in organizing each ESP course. It might happen that learners' expectations and needs would not meet due to the wrong choice of material. Hutchinson and Waters (1992) believe that materials provide a stimulus to learning. Not only the good materials teach, but they also encourage learners to learn.

\subsection{English Efficiency}

Blum-Kulka (1982) believes that to make an effective language communication, more linguistic knowledge is required. In the theory of second language learning (Spolsky, 1989) individual language learners through listening and reading generally develop prior to a higher level through speaking and writing. Indeed, the language domains modify the communication for the language proficiency levels. The language domains are speaking, listening, writing and reading. Lisboa (2004) makes a definition for each of the language domains. According to Lisboa (2004), in speaking, a learner has to engage in oral communication in different situations purposely. Listening is the process of understanding, interpreting and evaluating spoken language in a variety of situations. Writing is being engaged in written communication in various forms purposely, and reading is the process of interpreting and evaluating the written language symbols and text with understanding and fluency.

Cravotta (1990) believes that people who use English for Tourism Purposes (ETP) are expected to endeavor to maintain their communicative communication ability, accuracy, and fluency. Mastering English for the people who work in the international tourism and service industry is essential and provides them with the linguistic tools needed to travel and to work in different chosen professions.

\subsection{Types of Activities with Text}

In ESP course, text as a learning material can be used for learning and practice. In fact, it can be a source for reading or communicative skills and new vocabulary. Concerning the ESP activities, it is needed to keep in mind the context that should be consistent with studying subject matter. Different activities can be used in ESP teaching, e.g. warming-up activities, receptive activities, productive activities, and follow-up activities.

Warming-up is a kind of preparing step. In warming-up activities, the teacher has to do pre-teaching, discussing questions concerning the topic and activation of new vocabulary or grammar structures. To raise the learners' interests and lead them to further problems various kinds of plays, collocation grids, puzzles and questionnaires can be used. According to Wallace (1992), warming-up activities are very important and essential phase on which the text working process depends.

Reading, listening and working with a text itself are the activities that belong to the receptive activities. Various reading strategies can be realized through the receptive activity, e.g. skimming, scanning, with or without translation, and informative. They have to lead to encouragement of the learners. In fact, language-based approaches e.g. gap-filling and jigsaw reading can also be identified or approaches relating to the content of the 
text. Both of them have to aim the learners to be as much active and reflexive as possible.

Productive activities are practicing of the acquired knowledge. This activity is working in groups and pairs or individual with teacher assist who takes notice of using the target language. To identify how the learners understand the given topic, summarization of the lessons should be done by the learners.

In follow-up activities, appropriate using of learned and developing need to be recognized. It can be done in a form of exercises and creative homework. Harmer (1991) draws a large scale of activities and skills that can be developed through the follow-up activities. They are making discussion and dramatic activities.

\subsection{Evaluation}

Course evaluation is the necessary part of learning and teaching the process. Evaluation is a motivating factor and displays the learners' progress or effectiveness of the course. It also discloses possible inadequacies that are not successfully covered. Based on what we in fact evaluate, various ways can be performed. According to Hutchinson and Waters (1992), two eminent levels of evaluation are learners' assessment and course evaluation. In ESP courses, a test can be the best way for learner assessment. Moreover, questionnaires, tasks, discussions and interview can be used for the purpose of learners' assessments. Hutchinson and Waters (1992) believe that, since ESP is concerned with the ability to perform particular communicative tasks, teachers need to find whether the content of the course meets the learners' expectation and if the learners are able to dispose of the new information and perform learned skills in a particular situation.

On the other hand, the same as learner evaluation, the course evaluation, aids to assess whether the characteristic features of designing the course were met. "In course evaluation, we need to involve all those who share the learning process in making the ESP course as satisfying to the parties as possible". (Hutchinson \& Waters, 1992, p. 156). Depending on course running and an individual situation, the evaluation can be done. This means that there is no specific time or priority for doing the evaluation. However, it is very important to be aware of giving feedback.

\section{Discussion}

In the modern world and with more emphasis on professional subjects and science at universities, language studies are often neglected. Consequently, English might remain a difficult language to major in spite the fact that the tourism service industry can benefit extremely from it and it can revive interest in learning languages. One of the major criteria in employing people in the tourism and hospitality sector is the English knowledge. Poor English proficiency and competency can result in hardness in attracting and entertaining the tourists. Therefore, it is crucial to consider the English language taught as a core subject at tourism higher education institutions and universities all over the world. Future studies and research need to be conducted in order to analyze the English language needs of tourism. These studies would expand institutional perspectives on how the English language preparation for tourism purposes could be appropriately improved.

Having looked at the learning tasks and textbooks in the teaching of English for the tourism and hospitality, we can figure out that each higher institute or university uses a different textbook that contains the materials collected by teachers from various sources. These sources include English for tourism and English for general purposes materials, and all of them comprise all the four English skills; speaking, listening, writing and reading. Vocabulary activities and grammar structures are also emphasized in these English sources. It is essential to have a variety of English learning activities that can assist the learners to improve their English skills for the tourism purposes. These activities can be letter writing, group discussion, role playing and etc. This can qualify and prepare them for their future occupations in international tourism.

It is supposed that teaching English for tourism and hospitality industry is achieved through a topic-based focus. This method of teaching fulfills the double role of providing a meaningful framework, and learners can develop their language skills and knowledge. Moreover, it avoids the too-evident repetition of language items they have already seen. Topic-based approach aids that the language items covered are those truly required within the field chosen.

\section{Conclusion}

The second language speakers of English who wish to be employed and work in the service industry and international tourism and those who aspire to learn English for tourism purposes (ETP) have to carefully regard the language they use and the context of the particular situation. Therefore, a complete and comprehensive curriculum of practical courses should be helpful and beneficial for them. A curriculum relating to English for the international tourism and service industry need to be carefully designed and created to suit the specific learners' needs and wants. The aim of these courses is to provide the learners with certain and definite level or a 
situation where the language is going to be utilized. Methods and contents have to be specific to equip the learners for the particular situation (Hutchinson \&Waters, 1987).

Considering the international tourism and hospitality, English will give a smooth path to aid the tourism employees to meet up with their professional linguistic requirements in a satisfactory manner and finally to improve the quality service in international tourism. In ESP courses appropriate and related teaching materials are required to be designed and prepared based on different employees' duties. Mastering English for tourism purposes provide the individuals with the linguistic tools needed for travelling or for working in a variety of chosen professions in tourism and hospitality sectors.

\section{References}

Afzali, K., \& Fakharzadeh, M. (2009). A needs analysis survey: The case of Tourism letter writing in Iran. ESP World, 8,1 .

Akyel, A., \&Yalcin, E. (1991). Principles involved in writing: An ESP text book for Turkish policemen. Journal of Human Sciences, 10(2), 1-25.

Al-Khatib, M, (2005). English in the Workplace: An Analysis of the communication Needs of Tourism and Banking Personnel. Asian EFL Journal, 7(2).

Barron, P., \& Arcodia, C. (2002). Linking learning style preferences and ethnicity: international students studying hospitality and tourism management in Australia. Journal of Hospitality, Leisure, Sport, and Tourism Education, 1(2), 15-27. https://doi.org/10.3794/johlste.12.25

Barron, P., \& Arcodia, C. (2002). Linking Learning Style Preferences and Ethnicity: International Students Studying Hospitality and Tourism Management in Australia. Journal of Hospitality, Leisure, Sport and Tourism Education, 1(2), 1-13. 2 https://doi.org/10.3794/johlste.12.25

Blue, G. M., \& Harun, M. (2003). Hospitality language as a professional skill. English for Specific Purpose, 22, 73-91. https://doi.org/10.1016/S0889-4906(01)00031-X

Blum-Kulka, S. (1982). Learning to say what you mean in a second language: A study of the speech act performance of learners of Hebrew as a second language. Applied Language, 3(1), 29-59. https://doi.org/10.1093/applin/3.1.29

Brieger, N., \& Sweeney, S. (1994). Grammar \& Functions. Prentice Hall.

Brunton, M. W. (2009). An evaluation of hostel employees' attitudes to general and specific English in their coursework. ESP World, 8.

Bühler, K. (1990). Theory of Language: the Representational Function of Language. Translated by D. F. Goodwin. Amsterdam: John Benjamins Publishing Company. https://doi.org/10.1075/fos.25

Cassidy, S. (2004). Learning styles: An overview of theories, models, and measures. Educational Psychology, 24, 419-444. https://doi.org/10.1080/0144341042000228834

Chang, W. Y. (2009). A needs analysis of applying an ESP program for hotel employees. Yu Da Academic Journal, 21, 1-16.

Chen, P. C., Chiu, W. Y., \& Lin, T. Y. (2011). A study constructing holistic English for specific purposes (ESP) curriculum model for tourism and hospitality English. Education Research Journal, 1(5), 84-93.

Choi, K. (2010).Needs analysis of students of Tourism English. In Proceeding of the10th Conference of PAAL (pp. 57-68).Seoul: Hanyang Womens' University. https://doi.org/10.3727/108354210X12904412050099

Cho, B. (2005).Usefulness and enjoyment of simulation activities for tourism major students. Modern English Education, 6(1), 3-17.

Conner, M. L. (2007). Introduction to learning styles. Ageless Learner, 1997-2007. Retrieved July 30, 2012, from http://agelesslearner.com/intros/lstyleintro.html

Cravotta, J. S. (1990). English for Tourism Purposes. A new approach in the field of English for Specific Purposes. Retrieved from http://www.espfortourism.blogspot.my/2012/05/english-for-tourism-purposes.html

Dann, G. (2001). The Language of Tourism: a Sociolinguistic Perspective (2nd ed.) Wallingford, UK: CAB International cop. https://doi.org/10.1016/S0160-7383(00)00007-4

Diaz, C. A., \& Scholfield, P. (2010). Reading comprehension and specialized vocabulary: Does tourism 
vocabulary predict treading comprehension better than general vocabulary? In Proceedings of the Language at the University of Essex Conference (pp. 1-13).

Dale, C., \& McCarthy, P. (2006). I like your style: The learning approaches of leisure, tourism and hospitality students studying generic modules. Journal of Hospitality, Leisure, Sport and Tourism Education, 5(2), 48-58. https://doi.org/10.3794/johlste.52.116

Dudley-Evans, T. (1998). Developments in English for specific purposes: A multi-disciplinary approach. Cambridge, England: Cambridge University Press.

Dudley-Evans, T., \& Maggie, J. J. (1998). Developments in English for Specific Purposes. Cambridge: CUP

Edwards, N. (2000). Language for business: Effective needs assessment, syllabus design and materials preparation in a practical ESP case study. English for Specific Purposes, 19(3), 291-296. https://doi.org/10.1016/S0889-4906(98)00029-5

Fuentes, A. C. (2004). The use of corpora and IT in evaluating oral task competence for tourism English. CALICO Journal, 22(1), 5-24.

Fleming, N. D., \& Mills, C. (1992). Not another inventory, rather a catalyst for reflection. To Improve the Academic, 11, 137.

Gardner, R. C. (2000). Correlation, causation, motivation and second language learning Acquisition. Canadian Psychology, 41, 1-24. https://doi.org/10.1037/h0086854

Graves, K. (1999). Teachers as course developers. Cambridge: Cambridge University Press.

Haggag, H. (2008). The effectiveness of a content-based program for developing English writing skills and languages proficiency of tourism and hospitality students. M.A. Dissertation. Egypt: Qena University.

Honey, P., \& Mumford, A. (1995). Using Your Learning Styles. London: Peter Honey.

Hortas, J. D. (2008). English for Specific Purposes. Retrieved from http://www.studyusa.com/articles/esp.asp.Retrieved Octover 11

Hsu, L. W. (2010). Learning gaming English by prospective casino dealers in Taiwan: An explorative study. Journal of Foreign Language Instruction, 4(1), 69-86. Retrieved July 31, 2012, from ProQuest database.

Hsu, L. (2011). The perceptual learning styles of hospitality students in a virtual learning environment: The case of Taiwan. Journal of Hospitality, Leisure, Sport, and Tourism Education, 10(1), 114-127. https://doi.org/10.3794/johlste.101.325

Hutchinson, T., \& Waters, A. (1987). English for Specific Purposes: A learning-centered pproach. Cambridge: Cambridge University Press. https://doi.org/10.1017/CBO9780511733031

Hutchinson, T., \& Waters, A. (1992). English for Specific Purposes: A learning centered approach. Cambridge: Cambridge University Press.

Huang, C. S. (2008). English Curriculum Planning for Hospitality. Proceedings of 2008 International Conference of Applied Foreign Languages, 138-140.

Jing, W. (2010). Integrated teaching English speaking for students planning to work in tourism business in Greater Mekong Sub-region area. Human Resources Development Journal, 1(1), 87-98.

Kuppan, A. (2008). An evaluation of an English course for hospitality management in a tertiary institution. Dissertation Abstracts International.

Laborda, J. G. (2003). Travel and tourism students' needs in Valencia: Meeting their professional requirements in the ESP classroom. ESP World, 2(5).

Laborda, J. G.(2005). Text book analysis of Travel and Tourism text books from the perspective of university students; attitudes towards English as foreign language learning. The Professional and Academic English: Newsletter of the IATEFLESPSIG, 27, 19-24.

Laborda, J. G. (2009). Using web-quests for oral communication in English as a foreign language for tourism studies. Educational Technology \&Society, 12(1), 258-70.

Lashley, C. (1999). On making silk purses: developing reflective practitioners in hospitality management education. International Journal of Contemporary Hospitality Management, 11(4), 180-185. https://doi.org/10.1108/09596119910263586

Lashley. C., \& Barron P. E. (2006). The learning style preferences of hospitality management students: 
observations from an international and cross cultural study. International Journal of Hospitality Management, 25(4), 552-569. https://doi.org/10.1016/j.ijhm.2005.03.006

Leslie, D., \& Russell, H. (2006). The importance of foreign language skills in the tourism sector: A comparative study of student perceptions in the UK and continental Europe. Tourism Management, 27(6), 1397-1407. https://doi.org/10.1016/j.tourman.2005.12.016

Lorenzo, F. (2005). Teaching English for Specific Purposes (ESP). Retrieved from $\mathrm{http} / / / \mathrm{www}$.usingenglish.com/teachers/articles/teaching-english-for-specific-purposes-sp.html

Lo, Y., \& Sheu, C. (2008). The design, implementation, and evaluation of an English tour guide project. The Asian ESP Journal, 4(2), 79-95.

Luka, I. (2009). Development of students' English for Special Purposes competence in Tourism studies at tertiary level. ESP World, 8, 4.

Martin, A., \& Davies, S. (2006). An evaluation of the language skills in Scottish hotels. Journal of Hospitality, Leisure, Sport and Tourism Education, 5(1), 4-15. http://dx.doi.org/10.3794/johlste.51.94

McCarten, J. (2007). Teaching vocabulary: Lessons from the corpus, lessons for the classroom. Cambridge, Cambridge University Press.

Nunan, D. (1987). The teacher as curriculum developer: An investigation of curriculum processes within the Adult Migrant Education. South Australia: National Curriculum Resource Centre.

Robinson, P. C. (1991). ESP Today: A Practitioner's Guide. New York. Prentice Hall.

Robinson, P, C., \& Coleman, H. (2007). Working with Language: A Multidisciplinary Consideration of Language Use in Work Contexts. New York: Mouton de Gruyter.

Shieh, W. (2012). Hotel employees' perception on their workplace English use: An example from Taiwan. US-China Foreign Language, 10(11), 1729-1733.

Simion, M. O. (2012). The importance of teaching English in the field of tourism in universities. Annals-Economy Series, 2, 152-154.

Spolsky, B. (1989). Conditions for second language learning. Oxford: Oxford University Press.

Stapa, S. H. (2005). A survey of writing needs and expectations of hotel management and tourism students. ESP World, $1,9$.

Strevens, P. (1988). ESP after twenty years: A re-appraisal. In M. Tickoo (Ed.), ESP: State of the art (pp. 1-13). SEAMEO Regional Language Centre. Cambridge University Press

Tipmontree, S. (2007). The use and the problems of English and intercultural communication skills of Thai tourist police officers. M.A. Dissertation. Thailand: University of the Thai.

Tsao, C. H. (2011). English for specific purposes in the EFL context: A survey of student and faculty perceptions. Asian ESP Journal, 7(2), 126-149.

Tsao, C. H. (2008). English-learning motivation and needs analysis: a case study of technological university students in Taiwan. Paper presented at the Basic Research Conference of Chinese Military Academy on its 84th school anniversary. May 6, 2008. Fongshang, Taiwan.

Walqui, A. (2000). Contextual Factors in Second Language Acquisition. ERIC Digest. ERIC Clearinghouse on Language and Linguistics, Document ED444381, Washington, DC.

Watts, N., \& Trim, A. (1999). Utilization of immigrant language resources in international business, trade and tourism in New Zealand. New Settlers Program, Massey University.

\section{Copyrights}

Copyright for this article is retained by the author(s), with first publication rights granted to the journal.

This is an open-access article distributed under the terms and conditions of the Creative Commons Attribution license (http://creativecommons.org/licenses/by/4.0/). 